\title{
Physiological Responses in Growing Pigs Reared under Scavenging and Semintensive System
}

\author{
A. Chakraborty", S. Soren, S. Borah, G. Bordoloi, S. Payeng, K. Barman, S. Pathak, \\ U. R. Tamuly, S.S. Deka, P. Chabukdhara, K. Saikia and K. Boruah \\ Lakhimpur College of Veterinary Science, Assam Agricultural University, Joyhing, North \\ Lakhimpur, Assam, PIN- 787051, Assam, India \\ *Corresponding author
}

A B S T R A C T

\section{Keywords \\ Pig, Scavenging, Semintensive, Physiological response}

Article Info

Accepted:

07 January 2018

Available Online:

10 February 2018
The study was designed to assess the physiological responses in weaned male pigs reared under scavenging and semi-intensive system in Lakhimpur district of Assam, India. Fifty (50) nos. of weaned crossbred male pigs were selected for the study. 25 pigs were reared under scavenging system and 25 under semi intensive system. There was significant difference $\mathrm{P}<0.01$ in the respiration and pulse rate whereas temperature did not differ significantly.

\section{Introduction}

Diagnosing illness in animals represents one of the main duties of veterinarians. One very effective means to do so is based on a proper physical examination. The so-called clinical triad is of fundamental importance in clinical examination and consists of the measurement of rectal temperature (RT) as well as the evaluation of pulse and respiration.

Due to inadequate sweat glands, pigs depend on panting as their primary mechanism of heat dissipation (Patience et al., 2005), especially if they don't have access to a wallowing area.
The normal body temperature of the pig is $39.2^{\circ} \mathrm{C}\left(102.5^{\circ} \mathrm{F}\right)$ and at ambient temperatures above $22^{\circ} \mathrm{C}$ heat stress indicators such as increased respiration rates, and rectal temperatures are observed (Huynh et al., 2005). Nienaber and Hahn (2007) suggest that fast growing animals near market weight are at increased risk of severe heat stress because of increased metabolic heat due to genetic selection for enhanced lean tissue accretion rates. A $2.1 \%$ increase in lean tissue correlates with a metabolic heat production increase of 18.7\% (Brown-Brandl et al., 2004). Pigs respond to warm temperatures by increasing respiration rate, maximizing their surface area 
by laying on the ground, as well as increasing water intake. According to Marple et al., (1974), severe physiological changes can be observed in pigs with a rectal temperature reaching $41.5^{\circ} \mathrm{C}\left(106.7^{\circ} \mathrm{F}\right)$. The rearing system practiced by the farmers in this part of the region is mainly scavenging and semintensive, which also contributes to the variations in the physiological responses.

\section{Materials and Methods}

Hundred (100) nos. of weaned, crossbred male pigs of same age group and uniform size were selected for the study under the project 'Enhancing pig productivity by optimizing biomolecular expression through nutritional intervention in the existing system of pig Farming'. Fifty pigs were reared under scavenging system and fifty under semintensive system of pig rearing.

Rectal temperature was recorded with a digital thermometer by keeping the thermometer in contact with the rectal mucosa for about 2 minutes and expressed in degree celsius. Pulse rate was recorded by feeling the coccygeal artery and expressed in rate/min.

Respiration rate were recorded by visual observation of the inward and outward abdominal movement and expressed in rate/min. The data were recorded twice daily in the morning and in the evening and average was calculated as the final reading.

Care was taken to induce minimum disturbance to the animals.

\section{Statistical analysis}

Data were analysed using PRISM software. Different parameters are presented as mean \pm SE. Significance was assessed through ANOVA and level of significance was set at $\mathrm{P}<0.01$.

\section{Results and Discussion}

\section{Rectal temperature}

The mean rectal temperature did not differ significantly in the pigs reared under scavenging and semintensive system. Huynh et al., (2005) reported that the rectal temperature was affected by increasing temperature. Until the temperature reached $26.1^{\circ} \mathrm{C}$, the rectal temperature of pigs was constant at an average of $39.3^{\circ} \mathrm{C}$. Above that inflection point, it increased $0.13^{\circ} \mathrm{C} /{ }^{\circ} \mathrm{C}$. Quiniou and Noblet (1999) reported that the rectal temperature in the multiparous lactating sows was found constant between 18 and $22^{\circ} \mathrm{C}\left(38.6^{\circ} \mathrm{C}\right)$ but it increased at higher temperature $\left(39-39.4^{\circ} \mathrm{C}\right.$ between 25 and $29^{\circ} \mathrm{C}$ ). Rectal temperature increases when the physiological mechanism of an animal fails to negate the excessive heat load resulting in imbalance in the heat energy produced and dissipated.

\section{Respiration rate}

There was significant difference $(\mathrm{P}<0.01)$ in the mean respiration rate in the animals reared under scavenging and semintensive system.

It may be due to the fact that in scavenging system the animal movement is less restricted than that in semintensive system. Huynh et al., (2005) reported that with increasing temperature respiration rate remained constant at an average of 32 breaths / min until the inflection point (on average $22^{\circ} \mathrm{C}$ ) which increased by an average of 13 breaths $/ \mathrm{min} /{ }^{\circ} \mathrm{C}$ in pigs. Similar findings have been reported by Quiniou and Noblet (1999) who found that respiration rate in multiparous lactating sows increased from 26 to 124 breaths/min between 18 and $29^{\circ} \mathrm{C}$ and this indicates that the evaporative critical temperature was below $22^{\circ} \mathrm{C}$. The increase or decrease in respiration rates is an adaptive mechanism of an animal to 
maintain homoeothermic. In domestic animals respiration rate increases due to the activation of thermoreceptors in the skin when they are exposed to higher ambient temperature (Hafez, 1968). Such activation of the receptors in turn sends neural signals to the hypothalamus that increases respiratory activity to accelerate heat loss from the body by respiratory evaporation (Al-Haidary, 2004). An evaporative heat loss from the respiratory tract is regarded as one of the primary mechanism for maintenance of heat balance to maintain the internal body temperatures (Marai et al., 2007).

\section{Rearing System}

\begin{tabular}{|l|l|l|l|}
\hline $\begin{array}{l}\text { Rearing } \\
\text { System }\end{array}$ & $\begin{array}{l}\text { Rectal temperature }\left(^{\circ}\right) \\
\text { Respiration Rate } \\
\text { (rate/min) }\end{array}$ & $\begin{array}{l}\text { Pulse Rate } \\
\text { (rate/min) }\end{array}$ \\
\hline Scavenging & $39.12 \pm 0.033^{\mathrm{a}}$ & $51.06 \pm 0.32^{\mathrm{a}}$ & $77.11 \pm 0.15^{\mathrm{a}}$ \\
\hline Semintensive & $39.09 \pm 0.031^{\mathrm{a}}$ & $43.21 \pm 0.17^{\mathrm{b}}$ & $71.43 \pm 0.21^{\mathrm{b}}$ \\
\hline
\end{tabular}

Same superscript across the column do not differ significantly

\section{Pulse rate}

Statistical analysis revealed significant difference $(\mathrm{P}<0.01)$ in the mean pulse rate between the animals reared under scavenging and semintensive system. Similar pulse rate was reported by Peter et al., (2014). They reported a pulse rate of $60-90$ beats/min adult pigs but also suggested that the rates increase rapidly if the animals are stressed. The concomitant increase in the pulse rate along with the RR and the RT could be considered as an intrinsic physiologic mechanism. It reflects the homeostasis of circulation along with the general metabolic status. The present findings are in close proximity with the findings reported in The Normal Animal, Unit 1, 4-H Veterinary Science Programme (1977) where the pulse rate in pigs were in the range of 60 to 80 per minute.

Sipos et al., (2013) reported that the pulse rate in sows was more constant than the RT, which was found to depend strongly on the phase of the reproduction cycle. However, the pulse rate also reflected the exhaustion of farrowing, increasing to 110 beats/min from 94 beats/min on day 113 . There was also an increase in pulse rate by trend during insemination, followed by a decline afterwards. As observed for RT, pulse rate was generally slightly higher in gilts, especially in the period after their first farrowing with a mean of about 100 beats/min between day 3 and day 21. The pulse rate of adult boars was $96 \pm 17$ beats/min and that of juvenile boars was $104 \pm 13$ beats/min.

\section{Acknowledgement}

The article arouse based on the pilot survey conducted under the DBT, Government of India funded project entitled 'Enhancing pig productivity by optimizing biomolecular expression through nutritional intervention in the existing system of pig Farming'.

\section{References}

Al-Haidary, A.A. 2004. Physiological responses of Naimey sheep to heat stress challenge under semi-arid environments. Int. J. Agri. Biol., 6 (2): 307-309.

Brown-Brandl, T.M., Nienaber, J.A., Xin, H. and Gates, R.S. 2004. A literature review of swine heat production.Trans. ASAE, 47:259-27

Hafez, E.S.E. 1968. Adaptation of domestic animals.Lea and Febiger, Philadelphia, 
USA, pp 103.

Hyunh, T.T.T, Aarnink, A.J.A., Verstegen, M.W.A., Gerrits, W.J.J., Heetkamp, M.J.W., Kemp, B and Canh, T.T. 2005. Effects of increasing temperatures on physiological changes in pigs at different relative humidity. J. Anim. Sci. 83:1385-1396.

Marple, D.N., Jones, D.J., Alliston, C.W. and Forrest, J.C. 1974. Physiological and Livestock Prod. Sci., 96: 205-214.

Nienaber, J.A. and Hahn, G.L. 2007. Livestock production system management responses to thermal changes.Int. J. Biometeorol., 52:149157.

Patience, J.F., Umboh, J.F., Chaplin, R.K. and Nyachoti, C.M. 2005. Nutritional and physiological responses of growing pigs exposed to a diurnal pattern of heat stress. Livestock production science,
96:205-214.

Peter, G.G. Jackson and Peter, D. Cockroft 2014. Handbook of pig medicine.

Quiniou, N. and Noblet, J. 1999. Influence of high ambient temperatures on performance of multiparous lactating sows. American Society of Animal Science, 7:2124-2134.

Sipos, W., S. Wiener, F. Entenfellner and S. Sipos 2013. Physiological changes of rectal temperature, pulse rate and respiratory rate of pigs at different ages including the critical peripartal period. From the Clinic for Swine 1, Department for Farm Animals and Veterinary Public Health, University of Veterinary Medicine Vienna and the Veterinary Practice Entenfellner2, Stössing, Austria

\section{How to cite this article:}

Chakraborty, A., S. Soren, S. Borah, G. Bordoloi, S. Payeng, K. Barman, S. Pathak, U. R. Tamuly, S.S. Deka, P. Chabukdhara, K. Saikia and Boruah, K. 2018. Physiological Responses in Growing Pigs Reared under Scavenging and Semintensive System. Int.J.Curr.Microbiol.App.Sci. 7(02): 534-537. doi: https://doi.org/10.20546/ijcmas.2018.702.067 